\title{
PENGARUH DISIPLIN KERJA REKONSILIASI SATUAN KERJA DALAM APLIKASI E-REKON-LK TERHADAP KINERJA PEGAWAI BAGIAN SEKSI VERIFIKASI DAN AKUNTANSI PADA KANTOR PELAYANAN PERBENDAHARAAN NEGARA BUNTOK TAHUN 2020
}

\author{
The Effect of Working Unit Reconciliation Discipline in E-Recon-Lk Application on Employee \\ Performance in Verification and Accounting Section in Buntok State Budget Services Office 2020
}

\section{LISAWANTO}

STIE Dahani Dahanai, Buntok, Kalimantan Tengah, Indonesia.

Email: lisawanto@gmail.com

Keywords :

Work Discipline

Reconciliation

Performance

Service

Kata Kunci :

Disiplin Kerja

Rekonsiliasi

Kinerja

Pelayanan

Published

October 2020

\begin{abstract}
Abstrak
Penelitian ini bertujuan untuk mengetahui serta mendeskripsikan pengaruh Disiplin Kerja Rekonsiliasi Satuan Kerja pada Aplikasi e-Rekon-LK Terhadap Kinerja Pegawai Bagian Seksi Verifikasi dan Akuntansi pada Kantor Pelayanan Perbendaharaan Negara Buntok Tahun 2020 dan untuk mengetahui serta mendeskripsikan indikator yang paling berpengaruh pada disiplin kerja rekonsiliasi satuan kerja (Satker) dalam aplikasi e-Rekon-LK terhadap kinerja pegawai bagian seksi verifikasi dan akuntansi.

Teori yang digunakan dalam penelitian ini yaitu Disiplin Kerja menurut Bejo Siswanto (2019:291) dan teori kinerja pegawai menurut Agus Dwiyanto (2017:47). Penelitian ini menggunakan metode deskriptif kuantitatif dengan teknik pengumpulan data menggunakan observasi, wawancara, dokumentasi dan kuesioner. Penelitian ini mempunyai dua veriabel yaitu variabel independen $(X)$ disiplin kerja rekonsiliasi satuan kerja dalam aplikasi e-rekon-lk dan variabel dependen ( $Y$ ) kinerja pegawai bagian seksi verifikasi dan akuntansi. Alat analisis data yang digunakan yaitu Regresi Linier Sederhana dengan menggunakan SPSS Versi 25. Hipotesis dalam penelitian ini yaitu HI. Diduga terdapat pengaruh antara disiplin kerja rekonsiliasi satuan kerja (satker) dalam aplikasi e-Rekon-LK terhadap kinerja pegawai bagian seksi verifikasi dan akuntansi pada Kantor Pelayanan Perbendaharaan Negara Buntok Tahun 2020, H2. Diduga tingkat kewaspadaan dalam indikator disiplin kerja rekonsiliasi satuan kerja (Satker) dalam aplikasi e-Rekon-LK yang paling berpengaruh terhadap kinerja pegawai bagian seksi verifikasi dan akuntansi.
\end{abstract}

Hasil yang diperoleh dalam perhitungan regresi linier sederhana adalah $Y=10,946+0,765 X$ dimana nilai (a) sebesar 10,946 dan nilai koefisien (b) adalah 0,765. Kemudian diperoleh hasi thitung dari pengujian di atas bahwa thitung > ttabel $(5,876>2,035)$ maka Ho ditolak dan $\mathrm{Ha}$ diterima, artinya bahwa ada pengaruh secara signifikan antara Disiplin Kerja Rekonsiliasi Satuan Kerja (Satker) Dalam Aplikasi e - Rekon - LK terhadap Kinerja Pegawai Bagian Seksi Verifikasi dan Akuntansi Pada Kantor Pelayanan Perbendaharaan Negara Buntok Tahun 2020.

\section{Abstract}

This study aims to determine and describe the effect of Work Unit Reconciliation Work Discipline on the e-Rekon-LK Application on Employee Performance in the Verification and Accounting Section at the Buntok State Treasury Service Office in 2020 and to find out and describe the most influential indicators on work discipline unit reconciliation. work (Satker) in the e-Rekon-LK application on the performance of employees of the verification and accounting section.

The theory used in this research is Work Discipline according to Bejo Siswanto (2019: 291) and employee performance theory according to Agus Dwiyanto (2017: 47). This research uses descriptive quantitative method with data collection techniques using observation, interviews, documentation and questionnaires. This study has two variables, namely the independent variable $(X)$ work unit reconciliation discipline in the e-rekon-lk application and the dependent variable $(Y)$ the employee performance in the verification and accounting section. The data analysis tool used is Simple Linear Regression using SPSS Version 25. The hypothesis in this study is HI. It is suspected that there is an influence between the work unit reconciliation work discipline (satker) in the e-Rekon-LK application on the performance of employees of the verification and accounting section of the Buntok State Treasury Service Office 2020, H2. It is suspected that the level of vigilance in the work unit (Satker) reconciliation work discipline indicator in the e-Rekon-LK application has the most influence on employee performance in the verification and accounting section.

The results obtained in the calculation of simple linear regression are $Y=10.946+0.765 X$ where the value $(a)$ is 10.946 and the coefficient value (b) is 0.765 . Then the tcount is obtained from the above test that tcount $>$ ttable $(5.876>2.035)$ then $\mathrm{Ho}$ is rejected and $\mathrm{Ha}$ is accepted, meaning that there is a significant influence between Work Discipline Work Unit Reconciliation (Satker) in the eRekon-LK Application on the Performance of Section Employees Verification and Accounting Section at the Buntok State Treasury Service Office 2020.

(C) year The Authors. Published by Institute for Research and Community Services Universitas Muhammadiyah Palangkaraya. This is Open Access article under the CC-BY-SA License (http://creativecommons.org/licenses/by-sa/4.0/). DOI: https://doi.org/10.33084/restorica.v5i2 


\section{PENDAHULUAN}

Terselenggaranya good governance merupakan prasyarat bagi setiap pemerintahan untuk mewujudkan aspirasi masyarakat dalam mencapai tujuan serta cita cita bangsa bernegara. Dalam rangka mewujudkan hal tersebut diperlukan pengembangan dan penerapan sistem akuntabilitas kinerja penyelenggaraan pemerintahan dan pembangunan pemerintahan yang jelas, tepat, dan terukur sebagai bentuk tanggung jawab dalam mencapai misi dan tujuan instansi pemerintah yang mampu meningkatkan pelaksanaan pemerintah yang lebih berdayaguna, berhasil, bersih dan bertanggung jawab.

Bentuk pertanggungjawaban pemerintah kepada Stakeholder adalah laporan keuangan pemerintah. Masyarakat sebagai pihak yang memberikan kepercayaan kepada pemerintah untuk mengelola keuangan publik berhak untuk mendapatkan informasi keuangan pemerintah untuk melakukan evaluasi pemerintah. Akuntabilitas publik pengelolaan keuangan pemerintah dapat diwujudkan dengan penyajian laporan keuangan dengan penyajian laporan keuangan yang terdiri dari laporan periodik (perodic reports), laporan keuangan interim (interim finacial reports) dan laporan keuangan tahunan (annual financial reports).

Setiap perusahaan atau instansi sektor publik dalam melakukan aktivitasnya pasti melakukan tujuan yang hendak dicapai, untuk mencapai atau muwujudkan tujuan tersebut setiap organisasi / instansi sektor publik harus pandai dalam memilih strategi.

Sistem informasi menawarkan kemudahan komunikasi dengan memperpendek jarak dan mempersingkat waktu penyampaian informasi sehingga akan tercipta efisiensi komunikasi. Dengan adanya internet dan web, proses bisnis telah mengalami perubahan yang signifikan. Teknologi informasi telah digunakan secara luas untuk pengambilan keputusan, kemudahan pengoperasian, komunikasi, pencatatan dan untuk memperoleh produktivitas yang lebih tinggi di mana sistem digunakan. Teknologi informasi telah membuka fungsi baru dalam bisnis seperti proses bisnis berbasis web dan mengelola bisnis dari mana saja tanpa harus berada di kantor atau organisasi.

Pengembangan dan implementasi teknologi informasi menjadi salah satu bagian dari upaya pencapaian visi Ditjen Perbendaharaan untuk menjadi pengelola perbendaharaan negara yang unggul di tingkat dunia. Ditjen Perbendaharaan terus membuat kebijakan arah pengembangan transaksi di pemerintahan agar dilakukan dengan mengacu pada prinsip e-governmen. Salah satu contohnya adalah implementasi e-Rekonsiliasi Laporan Keuangan.

E-Rekon-LK merupakan aplikasi berbasis web untuk mendukung pelaksanaan rekonsiliasi antara Kantor Pelayanan Perbendaharaan Negara (KPPN) dan satuan kerja (satker) sekaligus proses konsolidasi laporan keuangan kementerian negara/ lembaga.

Peraturan Menteri Keuangan Republik Indonesia Nomor 118 /PMK.06/2018 Tentang Sistem Akuntansi dan Pelaporan Keuangan Pemerintah Pusat Pasal I yang dimaksud Rekonsiliasi adalah proses pencocokan data transaksi keuangan yang diproses dengan beberapa sistem/subsistem yang berbeda berdasarkan Dokumen Sumber yang sama.

Pemerintah pusat mempunyai 24 ribu (pada tahun anggaran 2016 menerbitkan DIPA sebanyak 23.610 satker dan 3900-an satker yang masih mempunyai saldo neraca walaupun tidak menerima DIPA) lebih satuan kerja. Hal ini membutuhkan sistem akuntansi yang memadai untuk menyusun laporan keuangannya. Salah satu perangkat yang mendukung pelaksanaan sistem akuntansi adalah perangkat lunak komputer atau aplikasi komputer. Aplikasi yang digunakan saat ini adalah Sistem Akuntansi Instansi Berbasis Akrual (SAIBA). Unit Akuntansi mulai dari satuan kerja sampai dengan Kementerian Negara/Lembaga menggunakan aplikasi SAIBA. Sehingga ada aplikasi SAIBA tingkat satuan kerja sampai dengan tingkat Kementerian Negara/Lembaga. Data SAIBA satuan kerja setiap bulan direkonsiliasi dengan Kantor 
Pelayanan Perbendaharaan Negara (KPPN) untuk validasi data. Rekonsiliasi ini juga dilakukan pada tingkat wilayah sampai dengan Kementerian Negara/Lembaga.

Aplikasi SAIBA telah berhasil mengantarkan sebagian besar laporan keuangan Kementerian Negara/Lembaga mendapat opini Wajar Tanpa Pengecualian (WTP) dan Laporan Keuangan Pemerintah Pusat (LKPP) mendapat opini Wajar dengan Pengecualian pada tahun 20I5. Disamping keberhasilannya, SAIBA menyisakan sedikit masalah dalam implementasinya.

Pada tahun 2016, pemerintah merilis aplikasi berbasis web e-Rekon-LK yang didesain memberi solusi atas masalah yang masih tersisa dalam Aplikasi Sistem Akuntansi Instansi Berbasis Akrual (SAIBA). Aplikasi eRekon-LK dirancang karena adanya temuan kinerja oleh Badan Pemeriksa Keuangan (BPK) atas pengendalian internal. Badan Pemeriksa Keuangan (BPK) terkait kelemahan pengendalian aplikasi, data yang dihasilkan system sebelumnya dinilai kurang efisien dan efektif dalam hal pelaksanaan rekonsiliasi dan pelaksanaan proses konsolidasi laporan keuangan.

Aplikasi e-Rekon-LK digunakan untuk mengkonsolidasi data seluruh Satuan Kerja dan untuk rekonsiliasi antara Satuan Kerja dengan data Kantor Pelayanan Perbendaharaan Negara (KPPN). Aplikasi berbasis web e-Rekon-LK mempermudah proses rekonsiliasi dimana rekonsiliasi laporan keuangan hanya ada pada satu level, yaitu level terendah antara Satuan Kerja dengan Kantor Pelayanan Perbendaharaan Negara (KPPN) yang dilakukan terhadap seluruh data transaksi keuangan untuk memenuhi prinsip-prinsip efektivitas dan efisiensi, serta akuntabilitas dan transparansi dalam pelaporan keuangan, tanpa mengurangi keandalan laporan keuangan itu sendiri.

Data valid hasil rekonsiliasi digunakan untuk penyusunan laporan keuangan tingkat wilayah sampai dengan tingkat Kementerian/Lembaga. Penggunaan data dengan single database pada e-Rekon-LK menyebabkan tidak diperlukan lagi rekonsiliasi tingkat wilayah sampai 58 dengan tingkat Kementerian/Lembaga. Hal ini dilakukan sebelum Laporan Keuangan yang disusun oleh satker selaku Unit Akuntansi Kuasa Pengguna Anggaran (UAKPA) maupun KPPN selaku Unit Akuntansi Kuasa Bendahara Umum-Daerah (UAKBUN-D) disampaikan kepada unit akuntansi di atasnya. Dengan dokumen sumber yang sama, pencatatan yang dilakukan oleh satker dengan KPPN seharusnya sama. Dalam mewujudkan hal tersebut, setiap unit atau satuan kerja Kementerian atau Lembaga dituntut untuk mempertanggungjawabkan pelaksanaan tugas pokok dengan didasarkan pada perencanaan strategis yang ditetapkan oleh masing-masing satker.

Rekonsiliasi penting dan wajib untuk dilaksanakan, untuk menjamin keandalan informasi yang akan dituangkan / disajikan dalam laporan keuangan. Dengan dokumen sumber yang sama, pencatatan yang dilakukan oleh UAKPA (satker) dengan KPPN seharusnya sama. Namun dengan pencatatan manual di satker sangat memungkinkan terjadinya kesalahan perekaman atau tidak direkam pada aplikasi (SAI) dalam e-Rekon-LK. Kesalahan mungkin juga bisa terjadi pada sistem di KPPN (SiAP) meskipun kemungkinannya kecil. Rekonsiliasi juga merupakan bentuk pengendalian internal dalam sistem akuntansi pemerintah untuk menghindari/meminimalisir kesalahan dalam penyusunan Laporan Keuangan Pemerintah Pusat (LKPP).

Untuk menyelaraskan persamaan data tersebut di dalam aplikasi e-Rekon-LK maka perlu adanya partisipasi Satuan Kerja agar tidak ada selisih dokumen keuangan antara Sistem Akuntansi Instansi (SAI) dan Sistem Akuntansi Pusat (SiAP). Karena jika terjadi permasalahan tersebut, dapat membuat kinerja pegawai Kuasa Bendahara Umum - Daerah (UAKBUN-D) menjadi kurang efektif.

Oleh karena itu perlu adanya disiplin kerja yang tinggi bagi semua pihak yang terlibat dalam menggunakan e-Rekon-LK. Disiplin kerja Menurut Bejo Siswanto (2010 : 29l) merupakan suatu sikap 
menghormati, patuh dan taat terhadap peraturanperaturan yang berlaku, baik tertulis maupun tidak tertulis serta sanggup menjalankan dan tidak mengelak untuk menerima sanksi-sanksi apabila ia melanggar tugas dan wewenang yang diberikannya kepadanya. Menurut Bejo Siswanto (2010 :291) Disiplin kerja dapat di ukur melalui 5 indikator yaitu diantaranya :

1. Frekuensi Kehadiran

2. Tingkat Kewaspadaan

3. Ketaatan Pada Standar Kerja

4. Ketaatan Pada Peraturan Kerja

5. Etika Kerja

Pada suatu organisasi/instansi sektor publik sangat diperlukan peranan berupa disiplin keja untuk meningkatkan kinerja pegawai, karena pegawai sangat menentukan tercapai atau tidaknya suatu tujuan dari organisasi atau instansi pemerintah sektor publik.

Kinerja pada dasarnya mencangkup sikap mental dan perilaku yang selalu mempunyai pandangan bahwa pekerjaan yang dilaksanakan saat ini harus lebih berkualitas daripada pelaksanaan pekerjaan masa lalu, untuk saat yang akan datang lebih berkualitas daripada saat ini. Kinerja yang baik merupakan keadaan yang diinginkan dalam dunia kerja.

Menurut Agus Dwiyanto (2017 : 47) konsep kinerja adalah Penilaian Kinerja yang merupakan suatu kegiatan yang sangat penting karena dapat digunakan sebagai ukuran keberhasilan suatu organisasi dalam mencapai misinya.

Kinerja yang lebih tinggi mengandung arti terjadinya peningkatan efisiensi, efektivitas dan kualitas yang lebih tinggi dari penyelesaian serangkaian tugas yang dibebankan dalam suatu organisasi / instansi sektor publik. Menurut Dwiyanto (2017:50) untuk mengukur kinerja birokrasi publik terdiri dari :

I. Produktivitas

2. Kualitas Layanan

3. Responsivitas

4. Responsibilitas
5. Akuntabilitas

Kantor Pelayanan Perbendaharaan Negara (KPPN) sebagai salah satu organisasi sektor publik selaku instansi vertikal dilingkungan Direktorat Jendral Departemen Keuangan Republik Indonesia (RI) yang menjalankan tugas dan fungsi sebagai Kuasa Bendahara Umum Negara (BUN) mempunyai peran penting dalam proses pencairan dana Anggaran Pendapatan dan Belanja Negara (APBN), Penatausahaan Penerimaan Negara dan pertanggungjawaban pelaksanaan anggaran.

Sejalan dengan reformasi birokrasi dalam rangka menuju tata laksana kelola pemerintah yang baik (good governance), Kantor Pelayanan Perbendaharaan Negara (KPPN) sebagai salah satu Aparatur Negara telah melakukan perubahan paradikma layanan dengan cara memberikan layanan yang cepat, tepat, akurat, tanpa biaya serta proses pekerjaan yang transparan (Dirjen Perbendaharaan : 2009).

Kinerja Organisasi dan Tata Kerja Kantor Pelayanan Perbendaharaan Negara (KPPN) disusun secara ringkas dan lengkap tentang capaian kinerja berdasarkan rencana kerja yang ditetapkan dalam rangka pelaksanaan Anggaran Pendapatan dan Belanja Negara (APBN).

Organisasi dan Tata Kerja Kantor Pelayanan Perbendaharaan Negara (KPPN) diatur dalam Peraturan Menteri Keuangan Nomor 169/PMK.0I/20I2 tentang Organisasi dan Tata Kerja Instansi Vertikal Direktorat Jenderal Perbendaharaan.

Kantor Pelayanan Perbendaharaan Negara (KPPN) Buntok merupakan Kantor Pelayanan Perbendaharaan Negara (KPPN) dengan type Al yang mempunyai tugas melaksanakan Kewenangan Perbendaharaan dan Bendahara Umum Negara, Penyaluran Pembiayaan atas beban anggaran, serta Penatausahaan dan Pengeluaran Anggaran melalui dan dari Kas Negara berdasarkan peraturan perundangundangan. Kantor Pelayanan Perbendaharaan Negara (KKPN) Buntok berada di Kecamatan Dusun Selatan, Kabupaten Barito Selatan, Buntok. 
Salah satu bagian yang diambil dalam penelitian ini yaitu bagian Seksi Verifikasi dan Akuntansi pada Kantor Pelayanan Perbendahraan negara (KPPN) Buntok. Uraian Tugas / Uraian Jabatan dari Seksi Verifikasi dan Akuntansi pada Kantor Pelayanan Perbendaharaan Negara (KPPN) Buntok yaitu melakukan rekonsiliasi laporan akuntansi, penyusunan laporan keuangan tingkat kuasa Bendahara Umum Negara (BUN), realisasi dan analisis kinerja anggaran serta analisis data statistik laporan keuangan regional.

Job Description (Uraian Jabatan) adalah suatu daftar tugas - tugas, tanggung jawab, hubungan laporan, kondisi kerja, tanggung jawab penyediaan suatu jabatan - jabatan produk dari analisis jabatan. (lke Kusdyah Rahmawati : 2008)

Job Description telah digunakan untuk menjelaskan mengenai tugas, pokok, fungsi, wewenang dan tanggung jawab masing - masing pegawai. Namun, uraian tugas secara formal hanya di ketahui oleh bagian kepegawaian sedangkan para pegawai umumnya hanya mengetahui uraian tugas tersebut dari kebiasaan ataupun arahan / penjelasan dari atasannya atau pegawai senior.

Salah satu bagian yang diteliti dalam uraian tugas seksi verifikasi dan akuntansi yaitu dalam melakukan rekonsiliasi laporan akuntansi antara satuan kerja selaku Unit Akuntansi Kuasa Pengguna anggaran (UAKPA) dengan KPPN Selaku Unit Akuntansi Kuasa Bendahara Umum - Daerah (UAKBUN - N) yang akan disampaikan kepada unit akuntansi di atasnya. Dalam melakukan rekonsiliasi, perlu adanya disiplin kerja dari satuan kerja dalam melaksanakan rekonsiliasi dalam e rekon - LK agar tidak ada selisih laporan keuangan antara Sistem Akuntansi Instansi (SAl) dengan Sistem Akuntansi dan pelaporan kuangan Pusat (SiAP), karena sering terjadi permasalahan pada satuan kerja yang kurang dalam melaksanakan disiplin kerja rekonsiliasi sehingga hal tersebut dapat berdampak rendah atau kurang baik terhadap kinerja pegawai bagian seksi verifikasi dan akuntansi, padahal yang berbuat kesalahan 60 bukan pegawai KPPN melainkan satuan kerja yang melakukan rekonsiliasi kurang teliti karena target rekonsiliasi harus 100\% agar tidak mengganggu laporan keuangan.

\section{METODE PENELITIAN}

Jenis penelitian ini merupakan penelitian deskriptif kuantitatif dengan melakukan pengujian hipotesis. Menurut Sugiyono (2017:7) metode penelitian kuantitatif dapat diartikan sebagai metode positivistik karena berlandaskan pada filsafat positivisme. Metode ini sebagai metode ilmiah/scientific karena telah memenuhi kaidah - kaidah ilmiah yaitu konkrit / empiris, objektif, terukur, rasional dan sistematis. Metode ini juga disebut metode discovery, kerena dengan metode ini dapat ditemukan dan dikembangkan berbagai iptek baru. Metode ini disebut metode kuantitatif karena data penelitian berupa angka - angka dan analisis menggunakan statistik.

Penelitian ini menggunakan pendekatan deskriptif dengan tujuan untuk mendeskripsikan objek penelitian atupun hasil penelitian. Adapun pengertian deskriptif menurut Sugiyono (2017:29) adalah metode yang berfungsi untuk mendeskripsikan atau memberi gambaran terhadap objek yang diteliti melalui data atau sampel yang telah terkumpul sebagimana adanya, tanpa melakukun analisis dan membuat kesimpulan yang berlaku umum.

Penelitian ini akan menjelaskan tentang hubungan kausal antara variabel independen yaitu Pengaruh Disiplin Kerja Rekonsiliasi Satuan Kerja (Satker) dalam Aplikasi e - Rekon - LK dan variabel dependen yaitu Kinerja Pegawai bagian Seksi Verifikasi dan Akuntansi pada Kantor Pelayanan Perbendaharaan Negara (KPPN) Buntok Tahun 2020.

Populasi dalam penelitian ini adalah seluruh Satuan Kerja yang ada di Barito Selatan, Barito Utara, Barito Timur dan Murung Raya pada Kantor Pelayanan Perbendaharaan Negara (KPPN) Buntok Tahun 2020 yang berjumlah 48 orang. 


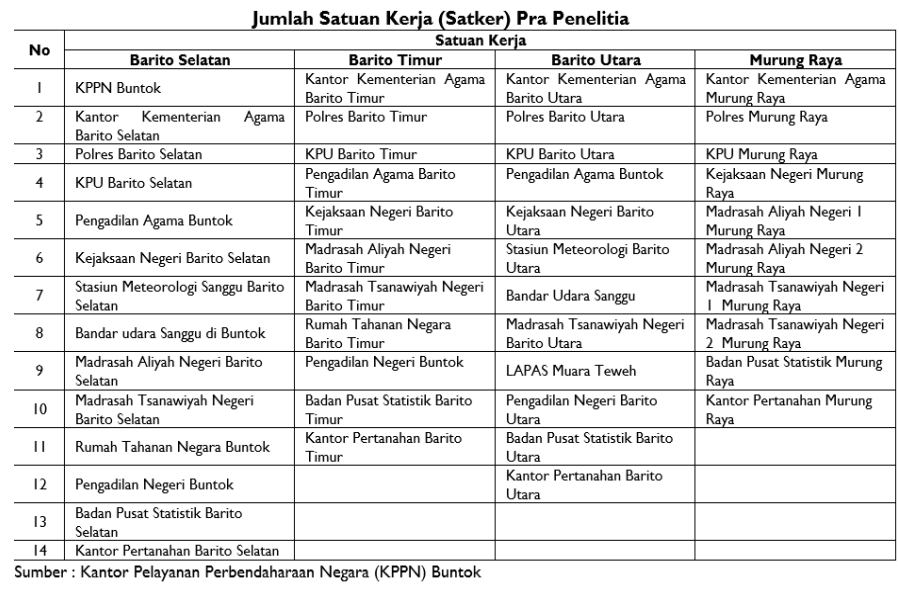

\section{HASIL PENELITIAN DAN PEMBAHASAN}

Dari hasil uji validitas bahwa indikator dari variabel $(X)$ Disiplin Kerja Rekonsiliasi Satuan Kerja (Satker) Dalam Aplikasi e-Rekon-LK, dengan pernyataan "Pegawai KPPN melakukan verifikasi rekonsiliasi pada aplikasi e-Rekon-LK sesuai dengan pedoman kerja yang berlaku" pada indikator (X) Ketaatan pada standar kerja, memiliki skor nilai paling tinggi yaitu 0,809.

Berdasarkan hasil uji validitas di atas untuk indikator Ketaatan pada standar kerja "Pegawai KPPN melakukan verifikasi rekonsiliasi pada aplikasi e-RekonLK sesuai dengan standar kerja yang berlaku" pada variabel Disiplin Kerja Rekonsiliasi Satuan Kerja (Satker) Dalam Aplikasi e-Rekon-LK (X), dapat dijelaskan bahwa hal tersebut sesuai dengan pendapat dari Fauzi R. Firdaus Pegawai KPPN Buntok Bagian Seksi Verifikasi dan Akuntansi tentang Pegawai KPPN melakukan verifikasi rekonsiliasi pada aplikasi e-Rekon-LK sesuai dengan standar kerja yang berlaku yaitu :

"Fauzi R. Firdaus mengatakan, Pegawai KPPN melakukan verifikasi rekonsiliasi pada aplikasi e Rekon - LK sesuai dengan pedoman kerja yang ada yaitu pedoman kerja yang sesuai dengan Standar Operasional Prosedur (SOP) yang ada di Peraturan Menteri Keuangan (PMK) dengan nomor PMK/2 I 0/20I7 tentang Pedoman Rekonsiliasi Dalam Rangka Penyusunan Laporan Keuangan. Pedoman kerja dalam bentuk Standar Operasional Prosedur (SOP) atau Peraturan Menteri Keuangan (PMK) di buat langsung oleh KPPN pusat yaitu Direktorat Jenderal Perbendaharaan."
Kemudian pendapat tersebut juga sama dengan keterangan dari Azhaarul Iman Pegawai KPPN Buntok Bagian Seksi Manajemen Satuan Kerja dan Kepatuhan Internal tentang Pegawai KPPN melakukan verifikasi rekonsiliasi pada aplikasi e-Rekon-LK sesuai dengan standar kerja yang berlaku yaitu :

"Azhaarul Iman mengatakan, Pegawai KPPN melakukan verifikasi rekonsiliasi pada aplikasi e Rekon - LK sesuai dengan pedoman kerja yang ada yaitu Pedoman kerja yang sesuai dengan Standar Operasional Prosedur (SOP). Didalam Standar Operasional Prosedur (SOP) itu sendiri sudah di atur tentang tugas dari masing - masing seksi maupun satuan kerja termasuk masalah rekonsiliasi itu sendiri. Standar Operasional Prosedur (SOP) tersebut dibuat di dalam Peraturan Menteri Keuangan (PMK) yang dibuat langsung oleh KPPN pusat atau Direktorat Jenderal Perbendaharaan.“

Berdasarkan dua pendapat dari hasil wawancara dengan Pegawai KPPN Buntok, Fauzi R. Firdaus pegawai Seksi Verifikasi dan Akuntansi dan Azhaarul Iman pegawai Seksi Manajemen Satuan Kerja dan Kepatauhan Internal, maka dapat di hubungkan dengan pendapat peneliti bahwa indikator Ketaatan pada standar kerja "Pegawai KPPN melakukan verifikasi rekonsiliasi pada aplikasi e-Rekon-LK sesuai dengan standar kerja yang berlaku" pada variabel Disiplin Kerja Rekonsiliasi Satuan Kerja (Satker) Dalam Aplikasi e-Rekon-LK (X) dalam melakukan rekonsiliasi sudah sesuai dengan standar kerja yang berlaku yaitu dengan berpedoman pada pedoman kerja dalam bentuk Standar Operasional Prosedur (SOP) yang kemudian Standar Operasinal Prosedur (SOP) mengikuti Peraturan Menteri Keuangan (PMK) dengan Nomor PMK/2 10/20I7 tentang Pedoman Rekonsiliasi Dalam Rangka Penyusunan Laporan Keuangan. Peraturan Menteri Keuangan (PMK) tersebut di buat langsung oleh Direktorat Jenderal Perbendaharaan.

Dari hasil uji validitas bahwa indikator dari variabel (Y) Kinerja Pegawai Bagian Seksi Verifikasi dan Akuntansi, dengan pernyataan "Pegawai KPPN selalu memiliki respon cepat tanggap dalam melakukan 
verifikasi rekonsiliasi pada aplikasi e - Rekon - LK" pada indikator (Y) Responsivitas, memiliki skor nilai paling tinggi yaitu 0,819.

Berdasarkan hasil uji validitas dan uji reliabilitas untuk indikator Responsivitas "Pegawai KPPN selalu memiliki respon cepat tanggap dalam melakukan verifikasi pada aplikasi e-Rekon-LK" pada variabel Kinerja Pegawai Bagian Seksi Verifikasi dan Akuntansi (Y), dapat dijelaskan bahwa hal tersebut sesuai dengan pendapat dari Operator Satuan Kerja Badan Pusat Satistik (BPS) Barito Selatan tentang Pegawai KPPN selalu memiliki respon cepat tanggap dalam melakukan verifikasi pada aplikasi e-Rekon-LK yaitu :

“Operator Satuan Kerja Badan Pusat Statistik (BPS) mengatakan, jika ada permasalahan seperti selisih data Sistem Akuntansi dan Pelaporan Keuangan Instansi (SAI) dan Sistem Akuntansi dan Pelaporan Keuangan Pusat (SiAP) yang ada di aplikasi eRekon-LK, Pihak KPPN dari Seksi Verifikasi dan Akuntansi akan langsung menghubungi operator Satuan Kerja secara pribadi melewati chatting WhatsApp ataupun chatting grup WhatsApp. Ketika Satuan Kerja melaksanakan rekonsiliasi pada aplikasi e - Rekon - LK di hari libur juga tetap bisa melaksanakan rekonsiliasi karena sudah dipermudah dengan sistem android."

Kemudian menurut Operator Satuan Kerja Kantor Kementerian Agama Barito Selatan tentang Pegawai KPPN selalu memiliki respon cepat tanggap dalam melakukan verifikasi pada aplikasi e-Rekon-LK yaitu :

“Operator Satuan Kerja Kementerian Agama mengatakan, jika terjadi selisih data Sistem Akuntansi dan Pelaporan Keuangan Instansi (SAI) dan Sistem Akuntansi dan Pelaporan Keuangan Pusat (SiAP) yang ada di aplikasi e - Rekon - LK, Pegawai Seksi verifikasi dan Akuntansi akan menghubingi satuan kerja melalui Via WhatsApp baik itu chatting pribadi maupun chatting grup untuk di berikan kabar upload ulang data ke dalam aplikasi e-Rekon-LK."

Kemudian menurut Operator Satuan Kerja Rumah Tahanan Negara (RUTAN) Barito Selatan tentang Pegawai KPPN selalu memiliki respon cepat tanggap dalam melakukan verifikasi pada aplikasi eRekon-LK yaitu :

62
"Operator Satuan Kerja Rumah Tahanan Mengatakan, Komunikasi pemberitahuan masalah Rekonsiliasi ke dalam aplikasi e - Rekon - LK, pihak KPPN yang akan menghubungi melalu chatting via WhatsApp baik pribadi maupun chatting grup."

Berdasarkan beberapa pendapat dari hasil wawancara dengan Satuan Kerja wilayah KPPN Buntok yang ada di Barito Selatan yaitu Badan Pusat Statistik (BPS) Barito Selatan, Kantor Kementerian Agama Barito Selatan dan Rumah Tahanan Negara (RUTAN) Barito Selatan, maka dapat di hubungkan dengan pendapat peneliti bahwa hasil indikator Responsivitas "Pegawai KPPN selalu memiliki respon cepat tanggap dalam melakukan verifikasi” pada variabel Kinerja Pegawai Bagian Seksi Verifikasi dan Akuntansi (Y) dimana dalam melakukan rekonsiliasi dalam aplikasi e-Rekon-LK, pegawai KPPN selalu memberikan respon cepat tanggap dalam memeriksa data Sistem Akuntansi dan Pelaporan Keuangan Instansi (SAI) dan Sistem Akuntansi dan Pelaporan Keuangan Pusat (SiAP) jika terjadi selisih angka, kemudian Pegawai KPPN Buntok juga langsung menghubungi satuan kerja melalui via WhatsApp sehingga satuan kerja lebih cepat dalam mengetahui informasi tentang rekonsiliasi data. Tidak hanya respon cepat tanggap di lingkungan kantor saja, tetapi diluar kantor pun pegawai KPPN Buntok bisa melakukan verifikasi rekonsiliasi melalui android sekalipun itu di hari libur kerja.

Hasil yang diperoleh dalam perhitungan regresi linier sederhana adalah $Y=10,946+0,765 X$ dimana nilai (a) sebesar 10,946 dan nilai koefisien (b) adalah 0,765 .

Pengaruh Disiplin Kerja Rekonsiliasi Satuan Kerja (Satker) Dalam Aplikasi e-Rekon-LK (X) nilai skornya adalah 0, sehingga Kinerja Pegawai Bagian Seksi Verifikasi dan Akuntansi (Y) nilai skornya sebesar 10,946. Kemudian koefisien regresi (b) pada variabel Disiplin Kerja Rekonsiliasi Satuan Kerja (Satker) Dalam Aplikasi e-Rekon-LK (X) sebesar 0,765, artinya jika nilai skor kinerja pegawai mengalami kenaikan sebanyak I kali maka Kinerja Pegawai Bagian Seksi Verifikasi dan 
Akuntansi (Y) akan mengalami peningkatan sebesar 0,765 serta koefisien akan bernilai positif, artinya terjadi hubungan positif antara Disiplin Kerja Rekonsiliasi Satuan Kerja (Satker) Dalam Aplikasi e-Rekon-LK dengan Kinerja Pegawai Bagian Seksi Verifikasi dan Akuntansi. Semakin tinggi nilai Disiplin Kerja Rekonsiliasi Satuan Kerja (Satker) Dalam Aplikasi eRekon-LK maka akan semakin meningkat Kinerja Pegawai Bagian Seksi Verifikasi dan Akuntansi.

Hasil dari penelitian ini dapat dihubungkan bahwa Disiplin Kerja Rekonsiliasi Satuan Kerja (Satker) Dalam Aplikasi e-Rekon-LK dapat meningkatkan Kinerja Pegawai Bagian Seksi Verifikasi dan Akuntansi. Sehingga Disiplin Kerja Rekonsiliasi Satuan Kerja (Satker) Dalam Aplikasi e-Rekon-LK dapat memberikan kontribusi yang bagus dan positif terhadap Kinerja Pegawai Bagian Seksi Verifikasi dan Akuntansi. Kemudian pada akhirnya Disiplin Kerja Rekonsiliasi Satuan Kerja (Satker) Dalam Aplikasi e-Rekon-LK terhadap Kinerja Pegawai Bagian Seksi Verifikasi dan Akuntansi dapat menghilangkan / menghindari sanksi dari KPPN Pusat bagi pegawai Seksi Verifikasi dan Akuntansi dengan kedisiplinan satuan kerja dalam melaksanakan rekonsiliasi. Berdasarkan hasil wawancara dengan Fauzi R. Firdaus Pegawai Bagian Seksi Verifikasi dan Akuntansi bahwa :

"Fauzi R. Firdaus mengatakan, jika Satuan Kerja tidak melaksanakan rekonsiliasi atau sudah melaksanakan rekonsiliasi tetapi data tidak valid sehingga terjadi selisih antara data SAI dan data SiAP maka akan mendapatkan sanksi dari KPPN berupa teguran dan tidak bisa mengajukan Surat Perintah Membayar (SPM)."

Penjelasan di atas dapat peneliti jelaskan bahwa selisih yang terjadi pada data Sistem Akuntansi dan Pelaporan Keuangan Instansi (SAI) dan Sistem Akuntansi dan Pelaporan Keuangan Pusat (SiAP) tersebut berupa selisih angka keuangan Satuan Kerja dari sisi Sistem Akuntansi dan Pelaporan Keuangan Instansi (SAI) dan selisih angka keuangan KPPN dari sisi Sistem Akuntansi dan Pelaporan Keuangan Pusat (SiAP). Biasanya selisih data tersebut muncul dari Satuan Kerja yaitu data
Sistem Akuntansi dan Pelaporan Keuangan Instansi (SAI) karena biasanya satuan kerja lupa mencatat Surat Perintah Pencairan Dana (SP2D) di aplikasi Sistem Aplikasi Satuan Kerja (SAS) yang dipegang oleh masing - masing satuan kerja, dimana Sistem Aplikasi Satuan Kerja (SAS) merupakan aplikasi berbasis dekstop yang digunakan sebagai sarana untuk membuat data kontrak, Rencana Penarikan Dana (RPD) harian, Surat Perintah Membayar (SPM) dan Laporan Pertanggungjawaban (LPJ) Bendahara bagia Satuan Kerja. Jadi ketika data masuk ke aplikiasi Sistem Akuntansi Instansi Berbasis Akrual (SAIBA) dimana aplikasi SAIBA tersebut merupakan terobosan aplikasi yang berbasis akrual yang diharapkan dapat memenuhi kebutuhan informasi laporan keuangan yang di isyaratkan oleh Standar Akuntansi Pemerintah, maka ketika direkonsiliasi akan menyebabkan data Sistem Akuntansi dan Pelaporan Keuangan Instansi (SAI) dan Sistem Akuntansi dan Pelaporan Keuangan Pusat (SiAP) terjadi selisih angka keuangan. Biasanya pelaksanaan pelaksanaan rekonsiliasi satuan kerja diberikan waktu oleh KPPN Buntok dari tanggal I sampai tanggal 12 setiap bulannya dan paling lambat tanggal I4 pada pukul 23.59 WIB.

Jika terdapat selisih data SAI dan SiAP maka KPPN Buntok akan menginformasikan kepada satuan kerja melalu via WhatsApp untuk memperbaiki data yang biasanya dilaksanakan pada minggu ketiga setiap bulannya.

Kemudian jika Satuan Kerja tidak memperbaiki selisih angka keuangan yang ada di data Sistem Akuntansi dan Pelaporan Keuangan Instansi (SAI) dan Sistem Akuntansi dan Pelaporan Keuangan Pusat (SiAP) dalam aplikasi e-Rekon-LK maka akan mendaptakan sanksi dari KPPN Buntok berupa teguran ataupun tidak bisa mengajukan Surat Perintah Membayar (SPM).

$$
\text { Lanjutan dari wawancara Fauzi R. Firdaus }
$$

Pegawai Bagian Seksi Verifikasi dan Akuntansi yaitu :

"Fauzi R. Firdaus mengatakan, hal tersebut juga bisa berdampak kepada Pegawai Bagian Seksi Verifikasi dan Akuntansi ataupun dapat juga berdampak pada 
Pegawai Seksi lainnya sekalipun itu Kepala Kantor yang mana sanksi tersebut di keluarkan langsung oleh KPPN Pusat.

Sanksi tersebut berupa menurunnya indeks kinerja pegawai seksi verifikasi dan akuntansi ataupun kinerja KPPN Buntok secara keseluruhan. Sanksi tersebut muncul akibat pegawai KPPN kurang berhasil dalam beredukasi dengan satuan kerja untuk melaksanakan rekonsiliasi, sehingga 2 belah pihak sebenarnya mendapatkan sanksi jika tidak disiplin."

Kemudian dapat peneliti jelaskan jika satuan kerja tidak melaksanakan selisih data keuangan pada aplikasi e-Rekon-LK yaitu data Sistem Akuntansi dan Pelaporan Keuangan Instansi (SAI) dan Sistem Akuntansi dan Pelaporan Keuangan Pusat (SiAP), lalu di beri teguran oleh KPPN Buntok tetapi satuan kerja tetap tidak melaksanakan perbaikan / revisi data Sistem Akuntansi dan Pelaporan Keuangan Instansi (SAI) sampai pada KPPN memberi teguran kedua tetapi tetap tidak melaksanakan revisi data Sistem Akuntansi dan Pelaporan Keuangan Instansi (SAI), sehingga KPPN Buntok memberikan sanksi tidak bisa mengajukan Surat Perintah Membayar (SPM) sampai pada akhirnya satuan kerja tetap tidak melaksakan rekonsiliasi atau tidak memperbaiki revisi rekonsiliasi dalam aplikasi e-RekonLK, maka pegawai seksi verifikasi dan akuntansi akan mendapat sanksi dari KPPN Pusat, tidak hanya seksi verifikasi dan akuntansi saja akan akan mendapat sanksi dari KPPN Pusat, akan tetapi Kepala Seksi sampai ke Kepala Kantor akan mendapatkan sanksi tersebut berupa menurunnya indeks kinerja pegawai. Hal tersebut bisa terjadi karena KPPN Pusat mengganggap KPPN Buntok tidak beredukasi dengan Satuan Kerja untuk melaksanakan rekonsiliasi dalam aplikasi eRekon-LK.

Jadi, untuk rekonsiliasi satuan kerja merupakan hal yang sangat penting sehingga tidak boleh ditinggalkan karena rekonsiliasi tersebut berhubungan dengan laporan keuangan Negara. Sehingga sanksi di jatuhkan tidak hanya untuk satuan kerja saja tetapi pegawai, kepala seksi dan kepala kantor yang ada di KPPN Buntok juga akan mendapatkan sanksi tersebut.
Kemudian lanjutan terakhir dari wawancara di atas oleh Fauzi R. Firdaus Pegawai KPPN Buntok Seksi Verifikasi dan Akuntansi yaitu :

"Fauzi R. Firdauz mengatakan, akan tetapi kasus tersebut hampir tidak pernah terjadi di KPPN Buntok karena Satuan Kerja Selalu Disiplin dalam melakukan rekonsiliasi setiap bulannya, sehingga pegawai KPPN Buntok ataupun Pegawai Bagian Seksi Verifikasi dan Akuntansi tidak pernah mendapatkan sanksi dari KPPN Pusat karena Satuan Kerja Wilayah KPPN Buntok selalu disiplin dalam melaksanakan rekonsiliasi pada aplikasi e-Rekon-LK.

Dapat peneliti jelaskan, namun kasus tidak melaksanakan rekonsiliasi ataupun tidak melaksakanakn revisi data Sistem Akuntansi dan Pelaporan Keuangan Instansi (SAI) dalam aplikasi e-Rekon-LK, hampir tidak pernah terjadi di KPPN Buntok, karena pegawai KPPN Buntok dan Satuan kerja selalu disiplin dalam melaksakan rekonsiliasi dalam aplikasi e-Rekon-LK. Pegawai KPPN selalu memiliki respon cepat tanggap dalam memverifikasi data Sistem Akuntansi dan Pelaporan Keuangan Instansi (SAI) dan Sistem Akuntansi dan Pelaporan Keuangan Pusat (SiAP) dalam aplikasi eRekon-LK sehingga pegawai KPPN tidak pernah mendapatkan / menerima sanksi dari KPPN Pusat dan Satuan Kerja yang ada di Barito Selatan, Barito Timur, Barito Utara dan Murung Raya hampir tidak pernah mendapatkan / menerima sanksi dari KPPN Buntok karena partisipasi Satuan Kerja yang ada di Barito Selatan, Barito Timur, Barito Utara dan Murung Raya selalu disiplin dalam melaksakan rekonsiliasi dan selalu disiplin dalam memperbaiki selisih data Sistem Akuntansi dan Pelaporan Keuangan Instansi (SAI).

Berdasarkan hasil wawancara di atas dapat dihubungkan dengan pendapat peneliti bahwa kedisiplinan Satuan Kerja dalam melaksanakan rekonsiliasi sangat berpengaruh sekali terhadap kinerja pegawai bagian seksi verifikasi dan akuntansi.

Partisipasi Satuan Kerja wilayah KPPN Buntok selalu disiplin dalam melaksanakan rekonsiliasi sehingga dapat memberikan kontribusi yang positif bagi pegawai 
seksi verifikasi dan akuntansi, sehingga indeks kinerja seksi verifikasi dan akuntansi selalu baik dan terhindar dari sanksi KPPN Pusat.

Berdasarkan Output di peroleh hasil thitung sebesar 5,876 dengan tingkat signifikan 0,05 atau 5\% yang sering digunakan sebagai ukuran standar dalam penelitian. Kemudian dalam menentukan $t_{\text {tabel }}$ dicari $\mathrm{a}=$ $5 \%: 2=2,5 \%$ (uji 2 sisi) dengan derajat kebebasan ( $d f$ ) $\mathrm{n}-\mathrm{k}-\mathrm{I}$ atau $36-2-\mathrm{I}=33$ (dimana $\mathrm{n}$ adalah jumlah sampel / responden dan $\mathrm{k}$ adalah jumlah dari variabel). Dengan uji 2 sisi signifikan 0,025 di peroleh hasil untuk $t_{\text {tabel }}$ adalah 2,035.

Dari hasil pengujian di atas bahwa $t_{\text {hitung }}>t_{\text {tabel }}$ $(5,464>2,035)$ maka Ho ditolak dan Ha diterima, artinya bahwa ada pengaruh secara signifikan antara Disiplin Kerja Rekonsiliasi Satuan Kerja (Satker) Dalam Aplikasi e-Rekon-LK dengan Kinerja Pegawai Bagian Seksi Verfikasi dan Akuntansi.

Bejo Siswanto (2010 : 291) menjelaskan pengertian disiplin kerja adalah :

"Suatu sikap menghormati, patuh dan taat terhadap peraturan - peraturan yang berlaku, baik tertulis maupun tidak tertulis serta sanggup menjalankan dan tidak mengelak untuk menerima sanksi - sanksi apabila ia melanggar tugas dan wewenang yang diberikannya kepadanya."

Artinya berdasarkan pendapat ahli di atas dapat disimpulkan bahwa dengan selalu disiplinnya satuan kerja dalam melaksanakan rekonsiliasi maka satuan kerja akan terhindar dari sanksi - sanksi KPPN berupa teguran ataupun tidak bisa mengajukan Surat Perintah Membayar (SPM). Menurut Agus Dwiyanto (2017 : 47) konsep kinerja adalah:

"Penilaian Kinerja merupakan suatu kegiatan yang sangat penting karena dapat digunakan sebagai ukuran keberhasilan suatu organisasi dalam mencapai misinya. Untuk organisasi pelayanan publik, informasi mengenai kinerja tentu sangat berguna untuk menilai seberapa jauh pelayanan yang diberikan oleh organisasi itu untuk memenuhi harapan dan memuaskan penggunaan jasa. Dengan melakukan penilaian terhadap kinerja, maka upaya untuk memperbaiki kinerja bisa dilakukan secara lebih terarah dan sistematis."
Artinya berdasarkan pendapat ahli di atas dapat disimpulkan bahwa dengan berhasilnya pegawai Seksi verifikasi dan Akuntansi dalam beredukasi dengan Satuan Kerja untuk melaksanakan rekonsiliasi maka akan memberikan kemajuan kinerja pegawai dalam mencapai Visi dan misi Organisasi dari KPPN Buntok.

\section{KESIMPULAN}

Berdasarkan hasil pembahasan dalam penelitian ini dapat diambil kesimpulan bahwa mengenai Pengaruh disiplin kerja rekonsiliasi satuan kerja (satker) dalam aplikasi e-Rekon-LK terhadap kinerja pegawai bagian seksi verifikasi dan akuntansi pada kantor pelayanan perbendaharaan negara (KPPN) buntok tahun 2020.

I. Dari hasil uji validitas bahwa indikator dari variabel (X) Disiplin Kerja Rekonsiliasi Satuan Kerja (Satker) Dalam Aplikasi e-Rekon-LK, dengan pernyataan "Pegawai KPPN melakukan verifikasi rekonsiliasi pada aplikasi e-Rekon-LK sesuai dengan pedoman kerja yang berlaku" pada indikator (X) Ketaatan pada standar kerja, memiliki skor nilai paling tinggi yaitu 0,809.

Berdasarkan dua pendapat dari hasil wawancara dengan Pegawai KPPN Buntok, Fauzi R. Firdaus pegawai Seksi Verifikasi dan Akuntansi dan Azhaarul Iman pegawai Seksi Manajemen Satuan Kerja dan Kepatauhan Internal, maka dapat di hubungkan dengan peneliti bahwa indikator Ketaatan pada standar kerja "Pegawai KPPN melakukan verifikasi rekonsiliasi pada aplikasi eRekon-LK sesuai dengan standar kerja yang berlaku” pada variabel Disiplin Kerja Rekonsiliasi Satuan Kerja (Satker) Dalam Aplikasi e-Rekon-LK (X) dalam melakukan rekonsiliasi sudah sesuai dengan standar kerja yang berlaku yaitu dengan berpedoman pada pedoman kerja dalam bentuk Standar Operasional Prosedur (SOP) yang kemudian Standar Operasinal Prosedur (SOP) mengikuti Peraturan Menteri Keuangan (PMK) 
dengan Nomor PMK/210/2017 tentang Pedoman Rekonsiliasi Dalam Rangka Penyusunan Laporan Keuangan. Peraturan Menteri Keuangan (PMK) tersebut di buat langsung oleh Direktorat Jenderal Perbendaharaan.

2. Dari hasil uji validitas bahwa indikator dari variabel (Y) Kinerja Pegawai Bagian Seksi Verifikasi dan Akuntansi, dengan pernyataan "Pegawai KPPN selalu memiliki respon cepat tanggap dalam melakukan verifikasi rekonsiliasi pada aplikasi eRekon-LK” pada indikator (Y) Responsivitas, memiliki skor nilai paling tinggi yaitu 0,819.

Berdasarkan beberapa pendapat dari hasil wawancara dengan Satuan Kerja wilayah KPPN Buntok yang ada di Barito Selatan yaitu Badan Pusat Statistik (BPS) Barito Selatan, Kantor Kementerian Agama Barito Selatan dan Rumah Tahanan Negara (RUTAN) Barito Selatan, maka dapat di dihubungkan dengan pendapat peneliti bahwa hasil indikator Responsivitas "Pegawai KPPN selalu memiliki respon cepat tanggap dalam melakukan verifikasi" pada variabel Kinerja Pegawai Bagian Seksi Verifikasi dan Akuntansi (Y) dimana dalam melakukan rekonsiliasi dalam aplikasi e-Rekon-LK, pegawai KPPN selalu memberikan respon cepat tanggap dalam memeriksa data Sistem Akuntansi dan Pelaporan Keuangan Instansi (SAI) dan Sistem Akuntansi dan Pelaporan Keuangan Pusat (SiAP) jika terjadi selisih angka, kemudian Pegawai KPPN Buntok juga langsung menghubungi satuan kerja melalui via WhatsApp sehingga satuan kerja lebih cepat dalam mengetahui informasi tentang rekonsiliasi data. Tidak hanya respon cepat tanggap di lingkungan kantor saja, tetapi diluar kantor pun pegawai KPPN Buntok bisa melakukan verifikasi rekonsiliasi melalui android sekalipun itu di hari libur kerja.

3. Hasil yang diperoleh dalam perhitungan regresi linier sederhana adalah $Y=10,946+0,765 X$ dimana nilai (a) sebesar 10,946 dan nilai koefisien (b) adalah 0,765.

Pengaruh Disiplin Kerja Rekonsiliasi Satuan Kerja (Satker) Dalam Aplikasi e-Rekon-LK (X) nilai skornya adalah 0, sehingga Kinerja Pegawai Bagian Seksi Verifikasi dan Akuntansi (Y) nilai skornya sebesar 10,946. Kemudian koefisien regresi (b) pada variabel Disiplin Kerja Rekonsiliasi Satuan Kerja (Satker) Dalam Aplikasi e-Rekon-LK (X) sebesar 0,765, artinya jika nilai skor kinerja pegawai mengalami kenaikan sebanyak I kali maka Kinerja Pegawai Bagian Seksi Verifikasi dan Akuntansi (Y) akan mengalami peningkatan sebesar 0,765 serta koefisien akan bernilai positif, artinya terjadi hubungan positif antara Disiplin Kerja Rekonsiliasi Satuan Kerja (Satker) Dalam Aplikasi e-Rekon-LK dengan Kinerja Pegawai Bagian Seksi Verifikasi dan Akuntansi. Semakin tinggi nilai Disiplin Kerja Rekonsiliasi Satuan Kerja (Satker) Dalam Aplikasi e-Rekon-LK maka akan semakin meningkat Kinerja Pegawai Bagian Seksi Verifikasi dan Akuntansi.

4. Hasil dari penelitian ini dapat dihubungkan bahwa Disiplin Kerja Rekonsiliasi Satuan Kerja (Satker) Dalam Aplikasi e-Rekon-LK dapat meningkatkan Kinerja Pegawai Bagian Seksi Verifikasi dan Akuntansi. Sehingga Disiplin Kerja Rekonsiliasi Satuan Kerja (Satker) Dalam Aplikasi e-Rekon-LK dapat memberikan kontribusi yang bagus dan positif terhadap Kinerja Pegawai Bagian Seksi Verifikasi dan Akuntansi. Kemudian pada akhirnya Disiplin Kerja Rekonsiliasi Satuan Kerja (Satker) Dalam Aplikasi e-Rekon-LK terhadap Kinerja Pegawai Bagian Seksi Verifikasi dan Akuntansi dapat menghilangkan / menghindari sanksi dari KPPN Pusat bagi pegawai Seksi Verifikasi dan Akuntansi dengan kedisiplinan satuan kerja dalam melaksanakan rekonsiliasi.

5. Bahwa selisih yang terjadi pada data Sistem Akuntansi dan Pelaporan Keuangan Instansi (SAI) 
dan Sistem Akuntansi dan Pelaporan Keuangan Pusat (SiAP) tersebut berupa selisih angka keuangan Satuan Kerja dari sisi Sistem Akuntansi dan Pelaporan Keuangan Instansi (SAI) dan selisih angka keuangan KPPN dari sisi Sistem Akuntansi dan Pelaporan Keuangan Pusat (SiAP). Biasanya selisih data tersebut muncul dari Satuan Kerja yaitu data Sistem Akuntansi dan Pelaporan Keuangan Instansi (SAI) karena biasanya satuan kerja lupa mencatat Surat Perintah Pencairan Dana (SP2D) di aplikasi Sistem Aplikasi Satuan Kerja (SAS) yang dipegang oleh masing - masing satuan kerja, dimana Sistem Aplikasi Satuan Kerja (SAS) merupakan aplikasi berbasis dekstop yang digunakan sebagai sarana untuk membuat data kontrak, Rencana Penarikan Dana (RPD) harian, Surat Perintah Membayar (SPM) dan Laporan Pertanggungjawaban (LPJ) Bendahara bagia Satuan Kerja. Jadi ketika data masuk ke aplikiasi Sistem Akuntansi Instansi Berbasis Akrual (SAIBA) dimana aplikasi SAIBA tersebut merupakan terobosan aplikasi yang berbasis akrual yang diharapkan dapat memenuhi kebutuhan informasi laporan keuangan yang di isyaratkan oleh Standar Akuntansi Pemerintah, maka ketika direkonsiliasi akan menyebabkan data Sistem Akuntansi dan Pelaporan Keuangan Instansi (SAI) dan Sistem Akuntansi dan Pelaporan Keuangan Pusat (SiAP) terjadi selisih angka keuangan. Biasanya pelaksanaan pelaksanaan rekonsiliasi satuan kerja diberikan waktu oleh KPPN Buntok dari tanggal I sampai tanggal 12 setiap bulannya dan paling lambat tanggal I 4 pada pukul 23.59 WIB.

Jika terdapat selisih data SAI dan SiAP maka KPPN Buntok akan menginformasikan kepada satuan kerja melalu via WhatsApp untuk memperbaiki data yang biasanya dilaksanakan pada minggu ketiga setiap bulannya. Kemudian jika Satuan Kerja tidak memperbaiki selisih angka keuangan yang ada di data Sistem Akuntansi dan Pelaporan Keuangan
Instansi (SAI) dan Sistem Akuntansi dan Pelaporan Keuangan Pusat (SiAP) dalam aplikasi e-Rekon-LK maka akan mendaptakan sanksi dari KPPN Buntok berupa teguran ataupun tidak bisa mengajukan Surat Perintah Membayar (SPM).

6. Kemudian dapat peneliti jelaskan jika satuan kerja tidak melaksanakan selisih data keuangan pada aplikasi e-Rekon-LK yaitu data Sistem Akuntansi dan Pelaporan Keuangan Instansi (SAI) dan Sistem Akuntansi dan Pelaporan Keuangan Pusat (SiAP), lalu di beri teguran oleh KPPN Buntok tetapi satuan kerja tetap tidak melaksanakan perbaikan / revisi data Sistem Akuntansi dan Pelaporan Keuangan Instansi (SAI) sampai pada KPPN memberi teguran kedua tetapi tetap tidak melaksanakan revisi data Sistem Akuntansi dan Pelaporan Keuangan Instansi (SAI), sehingga KPPN Buntok memberikan sanksi tidak bisa mengajukan Surat Perintah Membayar (SPM) sampai pada akhirnya satuan kerja tetap tidak melaksakan rekonsiliasi atau tidak memperbaiki revisi rekonsiliasi dalam aplikasi e - Rekon - LK, maka pegawai seksi verifikasi dan akuntansi akan mendapat sanksi dari KPPN Pusat, tidak hanya seksi verifikasi dan akuntansi saja akan akan mendapat sanksi dari KPPN Pusat, akan tetapi Kepala Seksi sampai ke Kepala Kantor akan mendapatkan sanksi tersebut berupa menurunnya indeks kinerja pegawai. Hal tersebut bisa terjadi karena KPPN Pusat mengganggap KPPN Buntok tidak beredukasi dengan Satuan Kerja untuk melaksanakan rekonsiliasi dalam aplikasi e-RekonLK.

Jadi, untuk rekonsiliasi satuan kerja merupakan hal yang sangat penting sehingga tidak boleh ditinggalkan karena rekonsiliasi tersebut berhubungan dengan laporan keuangan Negara. Sehingga sanksi di jatuhkan tidak hanya untuk satuan kerja saja tetapi pegawai, kepala seksi dan 
kepala kantor yang ada di KPPN Buntok juga akan mendapatkan sanksi tersebut.

7. Dapat peneliti jelaskan, namun kasus tidak melaksanakan rekonsiliasi ataupun tidak melaksakanakn revisi data Sistem Akuntansi dan Pelaporan Keuangan Instansi (SAI) dalam aplikasi e-Rekon-LK, hampir tidak pernah terjadi di KPPN Buntok, karena pegawai KPPN Buntok dan Satuan kerja selalu disiplin dalam melaksakan rekonsiliasi dalam aplikasi e-Rekon-LK. Pegawai KPPN selalu memiliki respon cepat tanggap dalam memverifikasi data Sistem Akuntansi dan Pelaporan Keuangan Instansi (SAI) dan Sistem Akuntansi dan Pelaporan Keuangan Pusat (SiAP) dalam aplikasi e-Rekon-LK sehingga pegawai KPPN tidak pernah mendapatkan / menerima sanksi dari KPPN Pusat dan Satuan Kerja yang ada di Barito Selatan, Barito Timur, Barito Utara dan Murung Raya hampir tidak pernah mendapatkan / menerima sanksi dari KPPN Buntok karena partisipasi Satuan Kerja yang ada di Barito Selatan, Barito Timur, Barito Utara dan Murung Raya selalu disiplin dalam melaksakan rekonsiliasi dan selalu disiplin dalam memperbaiki selisih data Sistem Akuntansi dan Pelaporan Keuangan Instansi (SAI).

8. Berdasarkan hasil wawancara di atas dapat dihubungkan dengan hasil uji Validitas bahwa kedisiplinan Satuan Kerja dalam melaksanakan rekonsiliasi sangat berpengaruh sekali terhadap kinerja pegawai bagian seksi verifikasi dan akuntansi. Partisipasi Satuan Kerja wilayah KPPN Buntok selalu disiplin dalam melaksanakan rekonsiliasi sehingga dapat memberikan kontribusi yang positif bagi pegawai seksi verifikasi dan akuntansi, sehingga indeks kinerja seksi verifikasi dan akuntansi selalu baik dan terhindar dari sanksi KPPN Pusat.

9. Berdasarkan Output di peroleh hasil $t_{\text {hitung }}$ sebesar 5,876 dengan tingkat signifikan 0,05 atau $5 \%$ yang sering digunakan sebagai ukuran standar dalam penelitian. Kemudian dalam menentukan $t_{\text {tabel }}$ dicari $\mathrm{a}=5 \%: 2=2,5 \%$ (uji 2 sisi) dengan derajat kebebasan (df) $\mathrm{n}-\mathrm{k}-\mathrm{I}$ atau $36-2-\mathrm{I}=33$ (dimana $\mathrm{n}$ adalah jumlah sampel / responden dan $\mathrm{k}$ adalah jumlah dari variabel). Dengan uji 2 sisi signifikan 0,025 di peroleh hasil untuk $t_{\text {tabel }}$ adalah 2,035. Dari hasil pengujian di atas bahwa thitung $>$ $t_{\text {tabel }}(5,464>2,035)$ maka Ho ditolak dan $\mathrm{Ha}$ diterima, artinya bahwa ada pengaruh secara signifikan antara Disiplin Kerja Rekonsiliasi Satuan Kerja (Satker) Dalam Aplikasi e-Rekon-LK dengan Kinerja Pegawai Bagian Seksi Verfikasi dan Akuntansi.

\section{REFERENSI}

Bastian, Indra. (200I). Akuntansi Sektor Publik di Indonesia. Edisi Pertama. Yogyakarta : BPFE.

Bodnar, H. George dan William S. Hopwood. (2006). Sistem Informasi Akuntansi. Edisi ke sembilan. Diterjemahkan oleh Julianto Agung Saputra. Jakarta : Andi.

Dwiyanto, Agus. (2006). Reformasi Birokraasi Publik di Indonesia. Yogyakarta : Gadjah Mada University Press.

Fathoni, Abdurrahmat. (2006). Manajemen Sumber Daya Manusia. Bandung : Renika Cipta.

Mahmudi. (2010). Manajemen Kinerja Sektor Publik. Jakarta : Sekolah Tinggi Ilmu Ekonomi YKPN.

Malayu, Hasibuan. (2002). Manajemen Sumber Daya Manusia. Jakarta : Bumi Aksara.

Mangkunegara, Anwar Prabu. (2007). Manajemen Sumber Daya Manusia Perusahaan. Bandung : PT. Remaja Rosdakarya.

Mardismo. (20I I). Perpajakan. Edisi Revisi. Yogyakarta : CV. Andi Offset.

Munawir, S. (20I4). Analisa Laporan Keuangan. Edisi Keempat. Yogyakarta : Liberty Yogyakarta.

Musanef. (2009). Manajemen Kepegawaian di Indonesia. Jakarta : PT. Gunung Agung.

Rachmawati, Ike Kusdyah. (2008). Manajemen Sumber Daya Manusia. Yogyakarta : Andi Offset.

Rasul, Sjahrudin. (2000). Pengukuran Kinerja Suatu Tinjauan pada Instansi Pemerintah, Lembaga Administrasi Negara. Jakarta.

Safaat H, Nazruddin. (2012). Pemprogaman Aplikasi Mobile Smartphone dan Tablet PC Berbasis Android. Edisi Revisi. Bandung. Informatika.

Sarwono, Jonathan. (2006). Metode Penelitian Kuantitatif dan Kualitatif. Yogyakarta : Graha Ilmu. 
Setiawan, Budi. (2013). Menganalisasi Statistik Bisnis dan Ekonomi Dengan SPSS 21. Yogyakarta : Andi Offset.

Simamora, Henry. (2006). Manajemen Sumberdaya Manusia. Yogyakarta : Sekolah Tinggi Ilmu Ekonomi YKPN.

Simanjuntak, J. Payaman. (20II). Manajemen dan Evaluasi Kinerja. Edisi 3. Jakarta : Lembaga Penerbit Fakultas Ekonomi Universitas Indonesia.

Siregar, Syofian. (20I5). Statistika Terapan Untuk Perguruan Tinggi. Jakarta : Kharisma Putra Utama.

Siswanto, Bejo. (2010). Manajemen Tenaga Kerja Indonesia Pendekatan Administratif Operasional. Jakarta : Bumi Aksara.

Siswanto, Bejo. (2019). Manajemen Tenaga Kerja Indonesia Pendekatan Administratif Operasional. Jakarta : Bumi Aksara.

Sugiyono. (2015). Metode Penelitian Kuantitatif, Kualitatif dan R\&D. Bandung : Alfabeta.

Sujarweni, Wiratna V. (20I5). Metodologi Penelitian Bisinis dan Ekonomi. Yogyakarta : Pustaka Barupress.

Sutrisno, Edy. (2016). Manajemen Sumber Daya Manusia. Jakarta : Kencana Prenada Media Group. (2010). Manajemen Sumber Daya Manusia. Edisi Pertama. Cetakan Pertama. Jakarta : Kencana.

Sunyoto, Danang. (20II). Metode Penelitian Ekonomi. Yogyakarta : CAPS.

Tika, H. Moh. Prambudu. (2006). Budaya Organisasi dan Peningkatan Kinerja Perusahaan. Cetakan Pertama. Jakarta : PT. Bumi Aksara.

Widjajanto, Nugroho.(200I). Sistem Informasi Akuntansi. Jakarta : Erlangga.

Yadiati, Winwin. (2007). Teori Akuntansi Suatu Pengantar. Jakarta : Kencana.

Peraturan Perundang - Undangan

Peraturan Menteri Keuangan Republik Indonesia Nomor 2I3/PMK.05/2013 Tentang Sistem Akuntansi dan Pelaporan Keuangan Pemerintah Pusat.

Peraturan Menteri Keuangan Republik Indonesia Nomor 215/PMK.05/2016 Tentang Sistem Akuntansi dan Pelaporan Keuangan Pemerintah Pusat.

Peraturan Menteri Keuangan Republik Indonesia Nomor I 8 / PMK.06 / 2018 Tentang Tata Cara Rekonsiliasi Barang Milik Negara Dalam Rangka Penyusunan Laporan Keuangan Pemerintah Pusat.

Peraturan Menteri Keuangan Republik Indonesia Nomor 262/PMK.01/2016 Tentang Organisasi dan Tata Kerja Instansi Vertikal Direktorat jenderal Perbendaharaan.

Peraturan Menteri Keuangan Republik Indonesia Nomor 104/PMK.05/2017 Tentang Pedoman Rekonsiliasi Dalam Penyusunan Laporan Keungan Lingkup Bendahara Umum Negara dan Kementerian Negara 